\title{
Semiotics Analysis of Semar Mesem Spell Performed by The Coastal Community of Jember, East Java, Indonesia
}

\author{
Roni Subhan ${ }^{1}$, Haris Supratno ${ }^{2}$, Darni ${ }^{3}$ \\ ${ }^{1,2,3}$ Language and Literature Education Study Program, Universitas Negeri Surabaya, Indonesia \\ roni.17070956002@mhs.unesa.ac.id
}

\section{Abstract}

The purpose of this study was to describe the symbolic meaning presented in Semar Mesem spell in its socio-cultural context. This study used text analysis by applying semiotic theory of Roland Barthes and considering its context in its social life of the community to obtain a comprehensive description of its symbolic meaning. The data was collected through direct interviews to the owner of spell. It was done by listening, transcribing it in English, identifying and analyzing it to formulate the research findings. The analysis showed that the symbols presented in the mantra described the elements of wisdom and virtue in communal life.

\section{Keywords}

semiotics; javanese coastal spell; symbolic meaning;

semar mesem

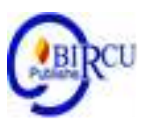

\section{Introduction}

The development of oral traditions in Indonesia is interrelated and complementary. Historically, it is always developing, keeping up with the times. Its development is influenced by social changes in society. Further, it could not be separated from the existence and development of oral literature. Both of them are interrelated since oral literature concerns with the existing traditional and cultural expression that have been disseminated and transmited from generation to generation.

The oral tradition as oral literature has lived in Javanese society for a long time. It has even continued to be encountered as the literary culture. Indonesia has evidently various oral traditions. Their existence has enabled people with their creative abilities to express themselves in artistic language. One of them is magic spell. It has become inherent in this Javanese Coastal society. Various activities are preceded by chanting it for the sake of achieving the desire to smoothly and safety carry out the people activities.

Spell is an oral tradition that develops and continues to live in the community, especially in marginalized communities, since it is inseparable from the culture of the local community. It is an oral tradition that has been continously cultivated in some Indonesian society. It can be seen in the existing spell which is classified as an old poetry. (Iroy Mahyuni. 2017)

Etymologically, Mantra or magic spell is derrived from of two syllables, Man (Manana) and Tra (Trana). It means freedom from the world's attachments which is often referred to samsara. This term literally means expected to come and it is called Amantrana. It is a single or combination of words believed to have magic power. It makes people able to cross to different world far beyond human reason. It is a tool or mean to take the people mind from the untrue things, full of errors to truth and wisdom (Wiana, 2004: 184). Titib (2003: 437) also stated that the speech of spell is a sacred expression functioning as a worship. Spell is a "model of mind ". Anyone who is able understand the meaning implied in it, he can manifest his mediated goals. It is arranged from a particular and regular words and syllables that produce a specific sound pattern and script. In addition, its sound pattern enables to move the intended person by its rhythm, timbre or sound (Titib, 2003: 439) 
Furthermore, spell is a language composition infused with a belief to the unseen world. It uses a unique and artistic language. Its diction is selected by adjusting it to a specific rhythm. Its meaning is produced based on a complicated, exhaustive, magical consideration, and it reflects a total submission for those considered the most supreme existence. Danandjaja (1997: 56)

The people living in the the coastal areas of Java, East Java, in carrying out their life activities, are inseparable from the spell. Therefore it is interesting to study its symbolic meaning based on its cultural context. Generally, the majority of Javanese coastal communities is Madurese and Javanese who continuely cultivate the teachings of their ancestors and preserve their heritage. One of them is the recitation of the spell in various activities. It has been a tradition of Jember Coastal areas. Therefore the recitation of the spell in their ritual activities was done in Krama Inggil in Javanesse language and Krama Tenggi in Maduresse language. Both of them are the highest level of language practice in the community.

The existence of the spell governed by the Javanese Coastal community has been continually preserved by passing it down orally to the younger members of the community. It is due to several factors 1) it is believed that the spell has a supernatural power of Khadam as its protector and guardian. Therefore it should be inherited directly. It is forbiden to do it through intermediaries or in any other forms since its violation can cause a fatal consequence. 2) In addition, it is believed that the spell can not be passed down to any member of society but it is for the people who are deemed worthy. (Pamalango, 2012).

These coastal communities are closely binded to the existing local traditions, stimulating various different literary works. The tradition of oral inheritance has been done from generation to generation. In addition, the spell of the Javanese coastal community has many local cultural symbols. They describe the existing culture that should be preserved all the time.

The data on the number of the existing spells are becoming scarce since the number of the inheritor in Jember coastal community is decreasing significantly. It is due to the impact of globalization. The next generation is increasingly indifferent to them. As a preservation effort, a detailed and in-depth study is needed to identify their presented symbols to preserve the culture. The framework of this research departed from the assumption that the spell is an ancestral heritage that has been continously preserved by the coastal communities of Jember. However, many spell speakers have died or they have been over than 40 years old. As the consequence, some of the spell have been diminishing or extinct.

\section{Review of Literature}

Semiotics was considered as a suitable theoretical design for studying the Semar Mesem spell of the coastal communities of Java Indonesia. Semiotics is associated with ethnography as a mean for bridging contextually through the association of signs related to the habits of a particular society in interpreting a sign or symbol that has become a common consensus. In addition, it was applied to describe the communication pattern carried out by the spell owners.

The study was carried out using Roland Barthes' semiotics which pays attention to the context of local culture. It was done since the culture of the coastal communities could be expressed and explained through text, context and local aspects (Endraswara. 2016). Barthes developes Saussure's signifier-signified concept into Expression (E) and Content (C). Expression which refers to the signifier, while the content represents the signified. 
Between the expression and the content, it is mediated by Relation (R). The concept of Relation makes the sign more dynamically developing since the Relation is created by the user of the sign. The use of signs always involves the usage of the E-R-C pattern. On the basis of this pattern, Barthes developes two levels of meaning. The first level is the primary system or denotative meaning. In this level, the signifier has a high degree of convention and explicit meaning. The second level of meaning is the connotative meaning and meta-language.

\subsection{Denotation}

Signs have literal meanings which describe their definitive meanings. These meanings are general in nature and they are the result of social consensus. These denotative signs do not represent myths and ideologies. They are signs at the first level and it merely provides material for constructing connotative and mythological signs at the second level. It was stated (Barthes, Griffin, 2003: 358) that the second level of meaning is developed from the sign at the first level which transform to be a connotative / mythic signifier.

\subsection{Connotation}

Connotation, according to Barthes' perspective, is a sign that already has been affected by the user's subjective feelings or emotions and his cultural values (Fiske, 1990). These signs are subjective and varied. It is due to the influence of the user's individual context that makes them diversely interpretated. The connotations were manifested in the form of various language styles aimed to uncover the hidden meanings.

In this regard, Rusmana (2014: 205) stated that actually through his connotative system, Barthes aims to uncover the hidden meaning of sign that has been considered normal because the signifier or Expression does not change at the second level of meaning. Ideological fragments are created from the usage of connotative signifier modified by the existing culture, knowledge and history.

Although Barthes does not explicitly state the actor who has created the false consciousness in the form of ideology, by showing the nature of the relationship between connotative signifier and motivated connotative signified and added by the role of power in sign creation, he aims not only to understand the meaning of signs based on an established system but also to uncover the hidden motives and messages behind the signs system. Rusmana (2014) stated that Barthes' semiotics seeks to uncover the secrets of signs, symbols and collective representations by focusing more on the connotative meaning system as the second level meaning system.

\subsection{Myth}

The term myth generally means a traditional belief governed by a particular community. However, Barthes provides a different definition of myth. Myth, according to Barthes, is inseparable from the facts governed by a society. It is a codification of social meanings and values as something natural through the naturalization of connotations. It makes the inherent hegemonic values are considered 'normal' and 'natural' by the member of society. Myth is contradictive in its nature. On the one hand, it is a cultural construction, but on the other hand, it is considered as a universal truth that had been established and generally accepted.

Myth, therefore, represents the concept of ideology. This was explained by Volosinov (1973) who stated that signs are related to ideology. According to Barthes, myths and ideologies are resulted from naturalized interpretations based on individual 
backgrounds. Thus, myth changes a particular world view into something that is naturally indisputable according to God's will (Barker, 2000: 74-75). Myth represents the second order of meta-language or semiology. It is described as the development of signs and meanings at the second level of meaning articulated into a system of ideology and myth.

Barthes correlates myth to ideology because they have the same nature of the relationship between denotative signifier and connotative signified. Both of them have a motivated correlation. The established system of connotations in society has turned into a myth. Furthermore, the established and massive myths are transformed into ideology. Because of their established and stable nature in society, these myths and ideologies are basically the result of the creation of connotative social meanings and values which are considered natural by the members of the society. Therefore, myths and ideologies represent hidden meanings and they create false consciousness in society.

This study also applied Hymes Ethnographic theory. Hymes' idea in ethnographic theory focusses on the communication process which underlines that the language element in the communication process is determined by several factors. Situation, participants, objectives, speech acts, way of speaking, tools used in speaking, norms and types of speech determine the speech which affects the act of the partners. All of these factors is resulted from the context of communication. In a case that a patient asks the spell owner to give and recite a spell for them, it is obvious that the speech uttered by both parties reflects their cultural value. Therefore, it is important to describe communication process involving the Javanese coastal community to understand the symbol represented in their spells.

Dell Hymes (. 1972) focusses on the use of language affected by social, psychological, cultural context. His concept of communication component is formulated in an acronym of "SPEAKING." Ethno-communication studies can be carried out using some of Hymes' concepts to get a comprehensive description of the concept. This concept covers: S: Scene which refered to: time, place and other physical conditions; P: Participants: Speakers or speech partners E: Ends or Purpose A: Act Sequences: Form and content K: Keys: Tone, serious or casual 1: Instrumentalities: Writing, chorus, teleposn, cellphone, dialect, standard language N: Norm G: genre: stories, commercials, dialogue, and so on

Contextually, the resulted speech is inseparable from the socio-cultural context of the involved speakers. In this case, the meaning of speech reflects the communication functions which is social in nature (Baumen \& Sherzer, and Pangaribun, 2008: 124). Therefore, the spell could only be understood in terms of language use within a tangible context of situation. The language functions, therefore, conveys the messages of speakers in achieving certain goals. Further, the language function then serves as the problem solving in order to fulfill certain social needs (Halliday, 1984). So, the meaning conveyed in speech is based on the social needs.

\section{Research Methods}

The approach used in this study was a qualitative approach. According to Cresswell (1998: 141) this approach is used to explore, understand and understand central issues. This method was carried out by understanding social symptoms from the perspective of the participant and the researcher. The selected informans were interviewed to collect and analyze data in the forms of opinions, thoughts, and views. The analysis was done by considering the context of the participants and its meaning. It included the participant feelings, beliefs, ideas, thoughts and activities during the interview. 
The steps in data collection were (1) making direct observations on the given spell and its intrepretation of symbols (2) conducting the data resulted from in-depth interviews to obtain primary data on the spell of Semar Mesem and its inherent practices (3) recording the process of interview to get the script of the spell and its communication pattern. The following activities were done during the interview (4) taking notes, transcribing the data. While the data analysis was carried out by, (1) identifying the collected data with the data corpus. Sorting and choosing the symbols and analyzing their meaning, (2) identifying the communication patterns of signs that function as symbol (4) describing the meaning of symbols represented in Semar Mesem spell.

This study used hermeneutic phenomenological approach. According to Maanen (1983), phenomenology is a description of life experiences, while hermeneutics described how people interprets the "text" of life. The basic model of the hermeneutic phenomenological approach is textual reflection on life experiences and practical actions of everyday life.

The hermeneutic phenomenological approach was chosen because it was relevant to the essence of the selected oral tradition. Literary works presented or created imaginative life through words, all of which originated from phenomena occuring in real human life in general. Literature is essentially a replica of human life experiences that have been processed and collaborated with the imagination of the author. In other words, this oral literature was the author's interpretation of the various realities of human life phenomena. Thus, literary research done in the phenomenological perspective, according to Endraswara (2013), has its own paradigm compared to other sciences. The main task of the researcher is to concretize the meaning underlied every phenomenon of human life reflected in the spell of Semar Mesem.

In this study, the hermeneutic phenomenological approach was used to interpret and describe the spell of Semar Mesem governed by the Javanese Coastal Society. The phenomenon of human culture as the focus of study in this study was the symbolic system presented in the spell which was used as the social control mechanism.

The procedure in applying the hermeneutic phenomenological approach in this study covered three approaches proposed by Manen (1990) consisting of the holistic reading, the selective reading, and the detailed reading approach. First, the holistic recitation of the spell was done by reading it as a whole and trying to find the reflected basic meaning. Second, the selective reading was done by selecting and highlighting parts of the spell that were difficult to interpret literally and confirming its meaning to the speaker. At this stage, the data were marked by being circled, underlined, or colored with a highlighter to make it easier to copy the data into the corpus. Third, the detailed reading was done by reading it in detail to find the essential meaning of the the spell of Semar Mesem.

\section{Discussion}

The research results described the symbolic meaning of the Semar Mesem spell in Barthes' semiotic perspective. The Semar Mesem spell presented various signifier of natural symbols, the world of wayang, Islam and Javanese mythology as the second level connotative signifier to manipulate the consciousness of the object of the spell. This spell was directed at fostering submission for the targeted person. The person was manipulated his conciousness by using the existing norms.

In addition, the spell presented the usage of natural forces, Javanese spiritualism, mysticism and magical powers symbols aimed to defeat or subdue other parties. It was one of the literary works in the form of oral tradition passed down to the choosen person who 
was considered compatible in receiving it. It was composed in words believed to have spiritual magic power by the speaker.

The spell of Semar Mesem was a spell that was believed and performed by the coastal community of Jember. It was a spell chanted by the speaker to gain compassion, attention and love of the targetted person. Lucik (interview 20 - 11-19) explained that the spell of Sema Mesem was a magic spell to make people amazed, attracted to love. Semar actually derrived from the name of a puppet character known as a character who had meaningful life orientation, full of an exemplary philosophy. Further, this character was described as a character who had sense of humor. He was known as the character who loved humanity in all aspect of life.

Sociologically, the coastal community of Jember consisted of Javanese, Madurese and Osing ethnic groups as the dominant inhabitants. It was reflected in the use of language, cultural values and cultural orientation reflected in the spell directed to get compassion.

This spell used names that refered to the characters in Puppet show. These figures included Srikandi who was a female wayang figure defeated Bisma in the Baratayudha war, Arjuna, a Pandawa knight who was skilled at archery and he was known for his good looking, Semar who was one of the punokawan figures acting as the caregiver for pandawa and Togok who was a character with Big nose, nasal voice, ugly and he served as the caregiver for the Kurawa. These characters qualities and traits were implicitly referred by the speaker of the spell. It aimed to imitate and animate the puppet characters to get the speaker wishes (Lucik, interview 19-02-20)

Puppet show, for the coastal community of Jember, was seen not only as a form of performance and entertainment but also a symbolic and spritual representation of life (Mulyono, 1989: 15). Therefore, puppet characters and stories were inseparable from their symbolic content. Furthermore, Mulyono stated that every character in the puppet has qulities to symbolize the type of human character and personality.

Mantra Semar Mesem

(F1.1b SeM 1-15)

"Srikandi abang iya lakinira

Arjuna

Aadegku togok lungguhku semar

Siro welas asih andulu badan

sliraku si.... (nama orang yang dituju)"
Semar Mesem Spell

(F1.1b.SeM 1-15)

Srikandi the red is your wife, Arjuna

I stand as Togok I take a seat as Semar

You are so loving, so loving body from

.... (the name of the targeted person)

I want my my charm of Semar Mesem

The use of the name of Semar as the name of the spell reflected the Javanese view on this puppet character. Semar was believed as the symbol of the lower class people power as he played his role as punokawan. At the same time, he was the incarnation of god who embodied the world. This figure had supernatural powers unmatched even by pandawa. This was stated by Lucik. (interview, 19-2-20), that Semar was a role model and source of strength for the Pandawas in defeating the Kurawa in Baratayuda war. According to him, with his supernatural powers, Semar was able to change anything in Marcapada, including changing ugliness into good looking like Arjuna.

The symbolic meaning in this spell was created on the base of the connotative use of the words and their combinations. It could be seen in: Srikandi the red is your wife, Arjuna 
I I stand as Togok I take a seat as Semar/You are so loving, so loving body from .... (the name of the targeted person)

The character of Togok and Semar (Lucik. 20-11-19) was a parable of bad posture that represented initial quality of the speaker which was transformed into a charming figure as Arjuno. Semar was believed to have full of wisdom in his attitude. His words could make people calm in facing all challenges. He was not only strong physically and mentally but also humorous. Meanwhile, Togok was a funny character. He was who had physical and mental strength and strong life principle.

This symbolically depicted a change in connotative meaning which was depicted through a change in physical form from ugly to handsome, from Togok and Semar to female charmers like Arjuna. By using puppet idioms that have been embedded in people's consciousness, the mythology in this mantra was built. It could be seen in the data (F1.3b SeM.5-8), I intend to chant my spell of Semar Mesem/ my power is the power of the universel my spell to get compasion and love is incurablel the most handsome is not else but melyou can not sleep and rest unless you meet me

It showed that the changing characters from ugly to enchantment derrived from the characters in puppet served to legitimize the undeniable magic character transformation of the spell speaker.

This ugly Semar characterization represented that the meaning of life could not justified based on the physical quality. Semar characters was considered to have a high level of authority as a clumsy and trusted punokawan. He was respected and friendly character. According to Sudarto, $(2000 ; 180)$ Semar in Arabic refered to Ismar which meant the nail. It symbolically had a strong reinforcing meaning. Further he was considered as the peace maker and controled and trancended the the anger. It actually symbolized the religion of Islam preached by Wali Songo when the Majapahit kingdom was in turmoil. Mulyono, (1989: 36). described that Semar body was irregular in shape. He could not described as male or female. He was not a god and a human. His characterization was fixed. He was considered as the balancing force who was able to harmonize the opposites. Meanwhile, Endraswara (2003: 2) stated that the representation of Semar and Togog was closely related to the mystical understanding of the Kejawen community represented by the abangan group. These two figures represented symbolic means of expression for the coastal community of Jember to express their will and aspirations. Therefore, it become the basis for the justification and legitimacy of the spell owner to conquer and attract the intended woman.

Furthermore, the speech presented in the spell described a specific communication pattern. In practice, it did not require a direct communication between the speaker and the intended object of the spell. The authority to determine its meaning depended on the speaker's perception and belief. Further, it reflected a type of speech that had certain norms inseparable from its cultural context. Therefore, this spell should be chanted in a sacred, wise and passionate situation in order to subdue defeat the opponent.

\section{Conclusion}

The spell of Semar Mesem for the coastal community of Jember Regency was considered as a compasion spell. It was a spell used to make people obey to others. In addition, it was a spell of affection to enchant the desired person. For instance, it was by a man to get the hearth of his desired woman or vice versa. Further, it was also used by a member of the community to gain specific authority in social life. 
This spell was a literary product of an oral tradition composed in words that were believed to have spiritual magic power by the speakers. In the process of recitation, it presupposes that this magic power was able to affect the desired person The speaker completely dominated the desired object.

It was also a form of speech that did not require direct communication process between the speaker and the targeted object. The meaning and function aimed by the speaker depended on how the speaker used his authority to realize his goal. Thus the speaker was decisive in directing its meaning through its specific function. It was a speech that had norms or rules done to get specific purpose. This was affected by his cultural in formulating his goals. His goals formulation was influenced by his cultural background.

The spell of Semar Mesem in the coastal area of Jember used religious knowledge and community traditions as the basis for speaker to construct mythology as his mean to conquer the desired objects. The speaker presented himself in the spell in the word of insun (I), who intended to subdue the object represented in the word of siro (you). In general, the speaker believed that they had personal qualities equal to those of the puppet characters. This made the intended object did not have other choice isntead of accepting and submiting herself to the speaker. The symbolic meaning of Semar Mesem spell was binded the cultural context of the speakers. It was carried out using a variety of spoken language indicated by the direct presence of the speaker in the text, the use of sound and rhyme patterns, and the repetition of words or lines.

\section{References}

Barker, Chris, (2004). Cultural Studies.Teori \& Praktik, Penerjemah: Nurhadi. Yogyakarta: Kreasi Wacana

Barthes, Roland. (1991) Mithologies , New Yoerk: Noonday Press,

Creswell. W. Jhon (1998). Qualitative Inquiry And Research Design: Choosing Among Five Traditions. London: SAGE Publications

Danandjaja, James. (1990). Folklor Indonesia: Ilmu Gosip, Dongeng, dan Lain-lain. Jakarta: Grafiti.

Endraswara, Suwardi. (2003). Mistik Kejawen: Sinkretisme,Simbolisme dan Sufisme dalam Budaya Spriritual Jawa . Yogyakarta: Penerbit Narasi

Em Griffin, (2003). A First Look at Communication Theory. McGrraw-Hill Companies

Fiske, John. (1990). Cultural and Communication Studies: Sebuah Pengantar Paling Komprehensif. Yogyakarta: Jalasutra

Halliday. (1994). Bahasa, Konteks, dan Teks. Aspek-aspek Bahasa dalam Pandangan Semiotik Sosial. Yogyakarta: Gajah Mada University Press

Hymes, Dell (1974). Foudations In Sosiolinguistics, New York: Tavistock Press

Manen, John Van, ed. (1983). Qualitative Methodology. Baverly Hills: Sage Publications,

Mulyono, Sri. (1989). Simbolisme dan Mistikisme dalam Wayang. Jakarta: PT Penerbit Indayu Press.

Mahyuni Iroy dan Sudartomo. (2017). Wacara Dukun Beranak Melayu Riau. Jurnal Caraka Vol 4 (1)

Pamalango, Valantino Ateng. (2012). Geografi Dialek Bahasa Saluan. Jurnal Parafrase Vol.12 (2).pp-299-309

Rusmana, Dadan. (2014). Filsafat Semiotika Paradigma, Teori, dan Metode Intrepretasi Tanda dari Semiotika structural hingga Dekonstruksi Praktis. Bandung: CV Pustaka Setia 
Sudarto, (2000), Interelasi Nilai Jawa dan Islam dalam Pewayangan dalam M. Darori Amin, 2002, Islam dan Kebudayaan Jawa,Gama Media Yogyakarta

Titib, I Made (2003). Teologi dan Simbol-simbol dalam Agama Hindu Surabaya : Paramita

Voloshinov, V. (1973) : Marxism and the Philosophy of Language. Massachusetts: Harvard University Press. Diakses dari http:// ebookbrowse.com

Wiana, I Ketut. (2004). Makna Upacara Yajna dalam Agama Hindu II. Surabaya: Paramita 